TEME, г. XLIV, бр. 2, април - јун 2020, стр. 441-460

Оригинални научни рад $\quad$ https://doi.org/10.22190/TEME180703001Z

Примљено: 3. 7. 2018.

UDK 005.591.6

Ревидирана верзија: 1. 4. 2020.

Одобрено за штампу: 15. 4. 2020.

\title{
A SYSTEMIC APPROACH TO IMPROVING INNOVATIVENESS IN HIGHER EDUCATION
}

\author{
Dejana Zlatanović ${ }^{*}$, Jelena Nikolić ${ }^{1}$, Zlatko Nedelkoº
}

${ }^{1}$ University of Kragujevac, Faculty of Economics, Kragujevac, Serbia ${ }^{2}$ University of Maribor, Faculty of Economics and Business, Maribor, Slovenia

*dejanaz@kg.ac.rs

\begin{abstract}
Innovativeness can be seen as a major competitive advantage in organizations enhancing their effectiveness and enabling the basis for sustainable development. Innovations in higher education systems have an impact on all the systems elements, relationships as well as on the higher order system in which higher education institutions (HEIs) are embedded, ranging from individuals to organizations. A holistic approach to innovativeness in higher education is required in order to improve innovativeness. The paper deals with the issues of improving innovativeness in higher education from the viewpoint of Soft Systems Methodology (SSM), as a relevant interpretive systems approach. The main purpose of this paper is to demonstrate how this systemic approach can help to explore the complex and pluralist nature of management innovativeness in higher education and provide a foundation for improving innovativeness of HEIs. Accordingly, the paper contributes to reveal different perceptions and interpretations of HEIs' relevant stakeholders on innovativeness, as well as to identify the systemically desirable and culturally feasible changes which can improve the innovativeness of HEIs. Findings will be useful for HEIs to improve their innovativeness.
\end{abstract}

Key words: innovation, improving innovativeness, higher education, Soft Systems Methodology.

\section{СИСТЕМСКИ ПРИЛАЗ УНАПРЕБЕЊУ ИНОВАТИВНОСТИ У ВИСОКОМ ОБРАЗОВАНУ}

\section{Апстракт}

Иновативност се може посматрати као кључна конкурентска предност у организацијама које настоје да унапреде своју ефективност и створе основу за одрживи развој. Иновације у систему високог образовања утичу на све елементе система, на односе између њих, као и на систем вишег реда у коме високообразовне институције функционишу. Наведено имплицира холистички прилаз управљању иновативношћу у високом образовању. Сходно томе, аутори се у раду баве релевантним питањима и проблемима управљања иновативношћу у високом образовању из перспективе Методологије тзв. софт система (МСC), као релевантног интерпрета- 
тивног системског прилаза. Кључна сврха рада је да се покаже како овај системски прилаз може да помогне у истраживању комплексне и плуралистичке природе управљања иновативношћу у високом образовању, као и стварању основе за унапређење иновативности у високом образовању. Допринос рада огледа се у откривању различитих перцепција и интерпретација које релевантни стејхолдери имају о управљању иновативношћу у високом образовању, као и препознавању системски пожељних и културално изводивих промена којима се може унапредити иновативност у високом образовању. Сазнања из овог рада биће корисна за високообразовне институције како би побољшале своју иновативност.

Кључне речи: иновације, унапређење иновативности, високо образовање, Методологија софт система.

\section{INTRODUCTION}

Innovation and creativity are widely accepted as the dominant factors of sustainable economic and social development. Since innovation contributes to reducing unemployment and increasing productivity, many researchers (e.g., Klomp and Van Leeuwen, 1999; Bouchikhi and Kimberly, 2001) see innovation as the long term key for improving domestic economies. As all sectors, higher education is not immune to this escalating global interest in innovation. Innovation will be essential to bring about qualitative changes in education in order to increase efficiency and improve the quality of learning opportunities (Tierney and Lanford, 2016). At the same time, higher education institutions (HEIs) play a crucial role in fostering creativity and innovation, by enabling the development of knowledge and skills, such as curiosity, intuition, critical and lateral thinking, risk taking and the ability to solve the problems and learn from failure (Valenčić-Zuljan and Vogrinc, 2010).

In accordance to the efforts of the European Union (EU) to become an innovation union and its Europe 2020 Strategy (European Commission, 2010), it is required to improve the distribution of knowledge, innovativeness as well as cooperation between academia and industry. Although innovation was "primarily explored in the domain of business organization and has been recognized as an important factor of organizational success (e.g. Rogers, 2003; Skarzynski and Gibson, 2008; Foss and Saebi, 2017), numerous studies (e.g. Carayannis and Rakhmatullin, 2014; Potocan, Nedelko, Mulej and Dabic, 2016) have also been dealing with innovativeness in higher education" (Zlatanović et al., 2020, p. 3).

When it comes to higher education, we argue that "innovation is a process of institutional adaptation to changes in the environment" (Zlatanović et al., 2020, p. 3), which encourage the improvement of HEIs and make them more innovative. Moreover, innovation also includes internal characteristics of HEIs, such as "organizational culture, strategies and structure (Hasanefendic, Birkholz, Horta, and van der Sijde, 2017). We can also observe innovation in higher education as a result of changing 
contexts in which HEIs function". (Zlatanović et al., 2020, p. 4) In this regard, the research of institutional factors that influence innovation, as well as the analysis of key stakeholders and their role in improving innovation in higher education is an important research area.

The overview of current literature about innovativeness in HEI reveals that it does not provide a deep insight into the core idea of innovativeness of HEI, which is reflected in lack of commonly accepted definitions of innovativeness that could reveal various facets of innovativeness in HEI, the current state of HEI innovativeness, etc. Focusing on another underrepresented field - drivers and barriers of innovativeness in HEI, it is evident that literature offers several studies, dealing with single or the few factors of innovativeness in HEIs, such as rapid development of technology (e.g. Garrison \& Kanuka, 2004). Although some studies consider simultaneously several drivers of innovativeness and admit the importance of using a holistic approach to study key drivers of innovation in HEIs (e.g. Serdyukov, 2017) they do not apply the tools of interpretive systems approaches to deal with these issues. To sum up, the current literature does not offer an overview of key drivers of HEI innovativeness which is important to design research approach for examining what drives innovativeness of HEI. Actually, there are no identified SSM applications in improving innovativeness in higher education (to the best of the authors' knowledge) and the lack of the definition of the drivers of innovativeness in HEIs represents an important research gap. Thus, the subject of research in this paper is the improvement of innovativeness of HEIs from the perspective of the SSM as an interpretive systems methodology. Based on the outlined research gap, the main goal of the paper is to show how this systems approach can help to explore the complex and pluralistic nature of improving innovativeness in higher education. On that note, rich pictures, root definitions and conceptual models will be used as relevant SSM tools. In this context, the paper addressed above outlines the lack in the literature and provides a holistic approach to key drivers of innovativeness in HEIs utilizing Soft Systems Methodology (SSM).

The main contribution of the paper is the systemic approach to improving innovativeness in HEI by utilizing Soft Systems Methodology, which has not been yet done in the literature. In that context, the aim of this paper is to outline the possible improvement of innovativeness of HEIs from the perspective of the (SSM), as an interpretive systems methodology. The contribution of the paper is seen in discovering the perceptions of different stakeholders on improving innovativeness in higher education, but also in identifying systemically the desirable and culturally feasible changes that could enhance innovativeness in higher education. Findings would be beneficial for HEIs to improve their innovativeness, using the proposed approach in the paper, which has not been previously considered nor used in HEIs. Next, another contribution 
is related to the identification of the key drivers of innovativeness in HEI, which will represent an important starting point for the future consideration of innovativeness in HEI from various viewpoints. Cognitions in this paper are also useful for further consideration of innovativeness in HEI - through focusing on different possible facets of innovativeness, the proposal of basic components of the instrument for surveying innovativeness in HEI, etc.

The paper consists of three logically connected entities. The first part refers to the key features and factors in improving innovativeness in higher education. The second part deals with the key theoretical-methodological and applicative features of the Soft Systems Methodology. With the aim of identifying the possible ways of improving innovativeness in higher education, the final part of the paper will use certain SSM tools that point to the significance of the different aspects of improving innovativeness and enabling the identification of areas for its improvement.

\section{INNOVATIVENESS IN HIGHER EDUCATION}

Innovation can represent any kind of novelty considered to be useful in practice. In other words, innovations always include certain inventions and their commercialization, where invention involves all new ideas that could become innovations. In fact, innovation is the result of a complex process that depends on different, interactive preconditions, which can be labeled as a dialectical system (Zlatanović and Mulej, 2015). In accordance with the above, the European Commission defines innovation as the "result of complex interactions between individuals, organizations and factors from the environment, and not as a linear trajectory from new knowledge to a new product" (European Union, 2006).

Innovativeness can also be seen as a multiphase process in which organizations transform ideas into new/advanced products, services or processes with the aim of enhancing competitiveness and successful differentiation on the market (Baregheh, Rowley and Sambrook, 2009).

HEIs should re-examine the existing models of functioning in order to provide knowledge and skills that students will need in the labor market. One of the preconditions for improving innovativeness in higher education is also the synergy which arises from the cooperation of different groups within the internal environment of HEIs (Lašáková, Bajzíková andDedze, 2017). Garcia and Roblin (2008) point out that it is important to facilitate internal cooperation and to stimulate team work, to encourage openness to new ideas and to distribute power. Nevertheless, despite efforts to support team work, organizational culture in HEIs often neglects it.

On that note, it can be pointed out that organizational culture at universities is often conservative and resistant to changes and that it has a tendency to maintain a status quo. Nedelko and Potočan (2013) particularly stress the importance of changing the organizational culture, i.e. changing 
the values and opinions, for improving innovativeness in modern organizations. Therefore, an innovative organizational culture is needed, characterized by resourcefulness, taking initiatives without prior instructions, morality in decision-making and taking responsibility, an environment that fosters innovativeness, teamwork, tolerance for failure and mistakes etc. (Roffeei et al., 2016). In order to create an innovative organizational culture, both the consistent support of the appropriate power structures and the political structures that create regulatory framework and leadership of HEIs are required. Moreover, there is a need for an institutional policy that supports innovation, the establishment of appropriate organizational structures in HEIs (for instance, a special organizational unit for improving innovativeness), as well as a strategic approach to the selection and evaluation of innovation. Also, according to Kunnari and Ilomäki (2016), the organizational structure and culture must be aligned with new, adaptive modes of learning, in order for integration and diffusion of innovation to be successful.

Despite the need for continuous institutional support, financial constraints and rigid regulation can be viewed as key barriers to improving innovativeness in higher education (Lašáková et al., 2017). In fact, another important barrier to innovativeness "in most European countries consists in restrictive national budgets for higher education" (Zlatanović et al., 2020, 5). In contrast, rapid development of technology can be seen as a driver of innovation and university development - for example, through fostering distance learning. However, despite the development of information and communication technologies, their impact on higher education is still minimal (Lašáková et al., 2017).

In order to improve innovativeness in higher education, it is necessary to create the conditions for sharing knowledge and information with other participants, increasing the level of individual commitment and looking for answers, creativity and innovative solutions. Consequently, the better understanding of the knowledge management process will stimulate innovative behavior (Zlatanović and Mulej, 2015).

Therefore, one can ask the question of how innovations in higher education can be measured. According to Oslo Manual definition, innovation in higher education institutions means their ability to produce and implement a new or enhanced process, product, or organizational method that has a significant effect on the activities of a higher education institution and/or its stakeholders such as students, communities, and firms (Brennan et al., 2014). In fact, innovation in HEIs can be measured through 1) new products and services, such as "developing and implementing new courses, research projects, teaching materials and curricula" (Zlatanović et al., 2020, p. 4 according to Al-Husseini and Elbeltagi, 2016); 2) new processes, such as elearning, good financial management or incentive reward systems for innovative staff members; 3 ) new ways of organizing the activities, such as 
using the ICT for purpose of communication with students and parents or implementation of short trainings for students and employees; 4) new marketing techniques, e.g. differential pricing of postgraduate courses or using the social networks to promote the activities (OECD, 2016, p. 16).

Considering the review of the relevant literature and especially relying on the results of the research conducted at ten different universities in the EU (Lašáková et al., 2017), it can be observed that the current state of innovativeness of higher education is characterized by the following features:

- the gap between the needs of HEIs and institutional, i.e. regulatory framework "(e.g. insufficient funding for this level of education, high bureaucracy demands, low information transparency, strict rules for accreditation, etc.)" (Zlatanović et al., 2020, 17);

- inadequate cooperation with the economy;

- the disparity of technological development (e.g. inconsistency of information and technology methods by individual departments);

- internal processes at HEIs (e.g. slow decision-making process, poor communication between different organizational units, poor coordination of activities, conservative and bureaucratic organizational culture);

- the rigid process of human resource management (e.g. rewarding that does not stimulate innovativeness, the teachers' workload, lack of material, technical and technological support);

- the characteristics of the teaching staff that discourage innovation (inadequate information and communication skills of the teaching staff, the negative attitude of the teaching staff towards changes (expressed, for instance, through job security as a primary care, without taking any risk), the application of conservative teaching methods);

- the characteristics of students that discourage innovation, such as insufficient motivation of students, the negative attitude towards innovation that can be seen in the following: preference of conventional teaching methods, unfamiliarity with innovative methods, lack of will, etc. (Ellis, 2015), inadequate information and communication skills of students, as well as the low level of involvement of students in decisionmaking.

With this in mind, we can highlight that "innovation can relate to one, several, or even all aspects of the educational system: theory and practice, teaching and learning, policy, curriculum, technology, administration, institutional culture, and teacher education. It can find its application in any aspect of education having the ability to positively affect learners and learning. At the same time, "innovation in higher education concerns all stakeholders: learners, parents, teachers, administrators, researchers, and policy makers and demands their active participation and support" (Zlatanović et al., 2020, p. 4, according to Serdykov, 2017). 
In general, innovation in higher education is a system of different parts and their relations. Simultaneously, this system belongs to a higher order system (e.g. economy). Therefore, a systemic approach to innovation can be applied, meaning that decision-making at HEIs cannot be an independent process, but it involves "more complex interactions among different organizations. Systemic approach enables identification of the key factors which (de)stimulate innovations, their interactions, interactions with relevant stakeholders, as well as examination of social and cultural context; infrastructure; organizational and institutional framework; processes of creating and transferring knowledge etc. One more argument is the fact that the above factors have a crucial impact on the level at which innovative decisions are made, as well as on the forms of innovation being implemented" (Zlatanović et al, 2020, p. 6, acording to Smith, 2000).

When applying traditional management tools to complex problems, certain limitations appear since complex problems become simplified into their constituent parts and then managed through discrete interventions. This simplification consists in isolation of actors and interventions, which disables complex problems of improving innovativeness to be properly addressed. A systemic approach to managing innovativeness in HEIs is "useful to reveal how the structure of the system affect its functioning, and what interventions can lead to better results" (Zlatanović et al., 2020, 3). Managing innovativeness in higher education can be studied as a complexpluralist problem situation for which the appropriate holistic instrumentarium is suitable (Petrović, 2013). Since improving innovativeness can be explored as complex-pluralist problem situation, some of the interpretive, i.e. soft systems methodologies can be applied. In the given context, the possible use of the interpretive Soft Systems Methodology will be presented. The main benefits of applying the SSM consists in discovering the perceptions of different stakeholders on improving innovativeness in higher education, their interactions at the national and supranational level, but also in identifying systemically desirable and culturally feasible changes that could enhance innovativeness in higher education. In fact, using the SSM enables the challenging of the existing ways of seeing and doing things, and can lead to some shifts in worldviews, opening up new proposals for change. These changes can be observed from two different perspectives: as the result of changes in the environment (e.g. changes of regulatory framework), or as the result of changes in the internal characteristics of the HEIs (e.g. organizational structure or culture).

\section{KEY FEATURES OF SOFT SYSTEMS METHODOLOGY}

The SSM represents a relevant interpretive systemic approach that tends to encompass different perceptions of reality, facilitating in this way the learning process in which different understandings are examined and discussed in a way that leads to deliberate action and improvement. Certain 
assumptions about society and social systems are also incorporated in the SSM. The social system is viewed as a constantly changing conception of the roles, norms and values of the participants, used for defining a particular situation. In managing a problem situation, the SSM is applied through the following four key phases (Checkland, 2000):

1. Examination of a problem situation using rich pictures and root definitions;

2. Building conceptual models;

3. Comparing the models with real world situations and

4. Taking action, i.e. implementing changes that will lead to improving the problem situation.

The initial expression of the problem situation is achieved by the construction of the so-called rich picture of a given situation that allows one or more viewpoints based on which the problem situation will be further investigated. Given that pictures, in general, are better means of perceiving and expressing different relationships than words, rich pictures involve key participants of some situation and show their interests, perceptions and interactions (Zlatanović and Nikolić, 2017).

The defined rich pictures can serve for the further development of the root definitions. The root definitions can be formulated as follows: a system that needs to do something that is marked with $\mathrm{P}$ by means of $\mathrm{Q}$ in order to achieve $\mathrm{R}$. The term 'to do $\mathrm{P}$ ' refers to a particular transformation to be carried out. The term 'by means of Q' denotes the activities necessary to do $\mathrm{P}$, that is, the activities needed to transform some input into the corresponding output. The term 'to achieve R' refers to the understanding of the world that makes the transformation meaningful. As an extended statement of the defined PQR model for the formulation of root definitions, the CATWOE model was also developed (Checkland and Tsouvalis, 1997).

The appropriate conceptual models are developed from the root definitions. The conceptual models themselves are the result of the answer to the question of what the system needs to do to be a system that is named in the root definition. While the root definition is an expression of what the system is, the conceptual model expresses the activities that must be undertaken by the system in order to be a system that is named in the definition (Checkland andTsouvalis, 1997). The elements of the conceptual model are verbs, i.e. verbal phrases that denote activities defined in the root definition. Experience has shown that the best way for building a conceptual model is to start with verbs that reflect the key activities contained in the root definitions.

As the final stage in the application of SSM in the structuring of problem situations, the comparison stage is the point in which intuitive perceptions of the problem situation are brought into conjunction with systemic structures, which ensures a deeper epistemological and more general expression of reality (Checkland, 1996, 177). The result of the comparison phase is the debate on possible changes arising from the 
appropriate assessment of the investigated problem situation. The debate on possible changes result in identifying the changes that meet the two key criteria: the first criterion consists in the fact that the changes must be systemically desirable, such as the introduction of the mechanisms of assessing effectiveness, ensuring that resources are adequate, etc. The second criterion relates to the cultural feasibility of changes ensuring that the elements of culture are not ignored, that is, providing respect for a certain world view, i.e. Weltanschauung, expressed in the root definition (Checkland, 1996, 181). Changes identified as systemically desirable and culturally feasible should be implemented, which represents the final stage of the application of the SSM. The practical usefulness of the SSM application in different studies is given in Table 1, identifying different areas of application of this methodology.

Table 1. Selected fields of SSM application

\begin{tabular}{ll}
\hline Fields of SSM application & Case studies \\
\hline Project management & Lockett et al., 2006 \\
Strategic management & Díaz-Parra et al., 2014 \\
Risk management & Majeand Sunjka, 2014 \\
Performance management & Jacobs, 2004 \\
Organizational design & Presley et al., 1998 \\
Quality management & Bennet and Kerr, 1996 \\
Information systems & Taylor et al., 2007 \\
Higher education & Yadin, 2013 \\
Innovation management & Loffler et al., 2009 \\
Efficient energy use & Neves et al., 2004 \\
Managing natural disasters & Gregory and Midgley, 2000 \\
Health protection & Fahey et al., 2004 \\
\hline \multicolumn{2}{c}{ Source: Authors }
\end{tabular}

As Table 1 shows, the SSM can be applied in different areas, based on which we can consider it a highly applicable methodology. Also, Table 1 shows that SSM has already been applied in the field of higher education. Nevertheless, it is of relevance to point out that, when it comes to researching the problem area of improving innovativeness in higher education from the perspective of the SSM, the appropriate application of this methodology in the given problem area has not yet been developed. Accordingly, a special contribution of the paper can be seen in removing the identified research gap.

\section{THE POSSIBLE APPLICATION OF THE SSM IN IMPROVING INNOVATIVENESS IN HIGHER EDUCATION}

Relying on previous considerations, a rich picture of the given problem situation can be built, as the first stage of the SSM application in improving innovativeness in higher education. On that note, based on the review of relevant literature and the results of previous studies, as well as 
on perceptions of the researchers themselves, the rich picture of the problem situation - improving innovativeness in higher education - was created (Figure 1). The rich picture encompasses the key stakeholders, their perceptions and interactions, such as students, the employees of HEIs, university and faculty management, the international cooperation of HEIs (expressed, for instance, in student and staff mobility), student organizations, the labor market, the local and state administration. The aim of creating a rich picture is to capture the main entities, relationships and viewpoints in the situation, the processes, the current and potential issues. As we can see from Figure 1, various stakeholders differently perceive innovativeness in higher education. For instance, local and state administrative concerns are related to the rules and procedures adopted on the national level, such as respecting the National strategy for higher education in which the key premises of innovativeness and its improvement are embedded. This strategy is also harmonized with the intentions of the European Union to become innovation union. Management at universities and faculties can observe innovativeness through the lenses of the continuous evaluation of teachers and reward system, which would stimulate innovativeness. Actually, mutual interactions between the management at universities/faculties and local and state administration can point to the need that the implementation of the national strategy and procedures for higher education should be enabled at faculties/universities, but also that some good practices should be involved in national procedures. Teaching and nonteaching staff through their interactions with students, the management at faculties/universities and businesses, may all perceive innovativeness as a means for continuous improvement of the quality of teaching and learning, improving creativity and entrepreneurial skills of students, etc. The relations among the students, labor market and the business sector are also emphasized in Figure 1. They indicate the importance of business-academia collaboration, gaining knowledge and competences according to the labor market's requests, as well as the possibility for students to adopt practical knowledge (e.g. through obligatory internship programs). Moreover, Figure 1 stresses the importance of the mobility of the students and the staff for improving innovativeness in higher education. Exchanging knowledge, experiences and practices, may results in better innovativeness through adopting new courses, teaching and learning methods, ways of students' assessment, etc. Therefore, Figure 1 presents a tool to encompass diverse perceptions, interests, opinions of stakeholders and their multiple relationships as well, i.e. a way of capturing impressions and insights. In fact, it represents innovativeness in higher education as a system of subjective people perceptions, i.e. as mental constructs of people involved in the problem situation. According to the rich picture presented (Figure 1), we can set the root definition, as a proper concise description of the system of improving 
innovativeness based on a specific world view. In order to facilitate the formulation of the root definition, the CATWOE analysis was used.

In this way, the following six components were identified:

C (Customers) - students, economy, society as a whole

A (Actors) - higher education institutions

T (Transformation Process) - traditional higher education institutions - transformation process - innovative higher education institutions

W (Weltanschauung) - contemporary higher education institutions function in circumstances where there is a pronounced significance of innovativeness in accordance with the EU's efforts to become an innovation union

O (Owners) - employees in higher education institutions

$\mathbf{E}$ (Environmental constraints) - restrictive legal regulations, financial constraints

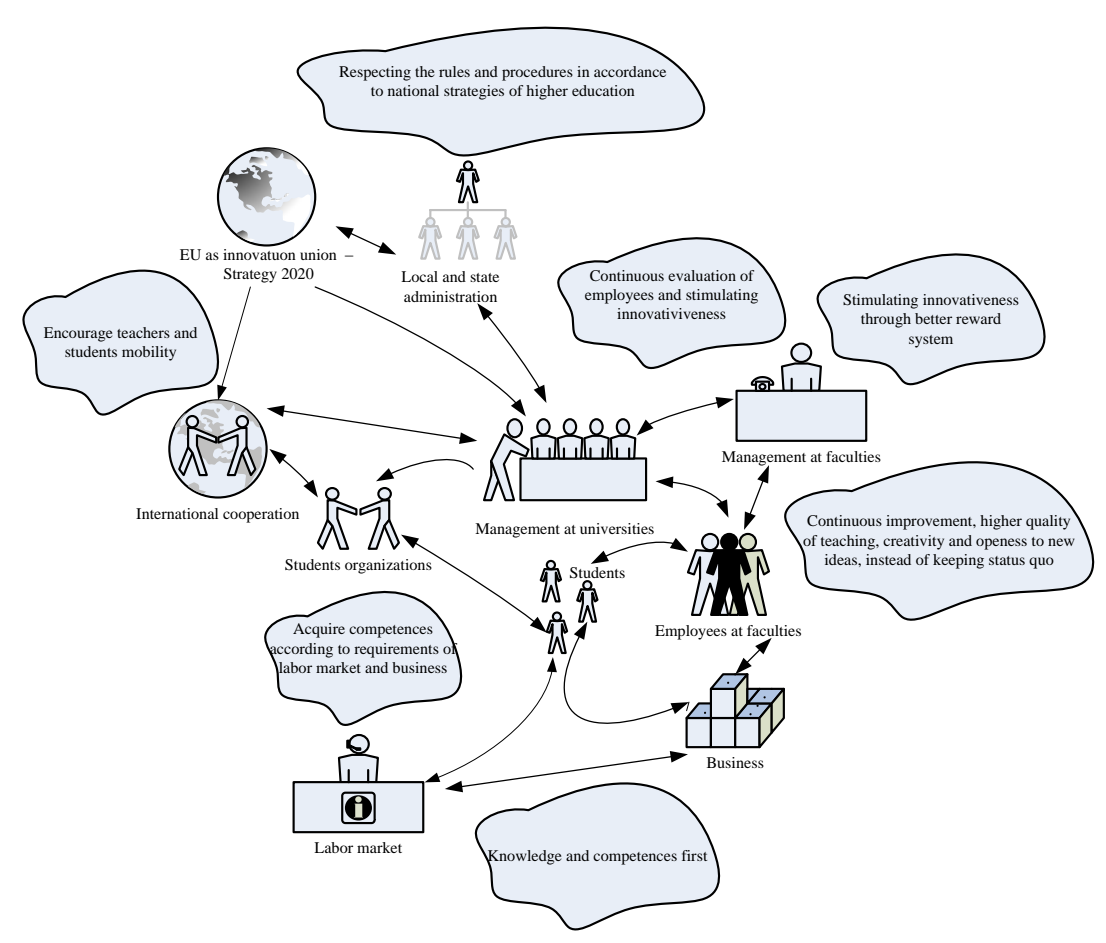

Figure 1 Rich pictures of the problem situation of improving innovativeness in higher education

Source: Authors 
The root definition from the presented CATWOE could be set as follows:

Relevant system: A knowledge-based system that involves a strategic approach to innovation along with intensive cooperation of HEIs with external stakeholders, new models of organizational structures, innovative organizational culture, continuous training and development of employees in HEIs, as well as greater participation of students in decision-making, which contributes to improving innovativeness and efficiency of higher education institution as a basis for sustainable development.

The next step in the implementation of the SSM is to build a conceptual model. Since the elements of the conceptual model are verbs, the modeling technique is reflected in the compilation of a minimal list of verbs denoting the activities necessary in the system described in the root definition, as well as in structuring the verbs in a logical order (Checkland, 1996, 170). The conceptual model is presented in Figure 2. Actually, the conceptual model defines and links the activities needed to achieve the transformation process. Modelling the current practice which cannot enable valid comparison phase and discussion in building the conceptual models seems to be the most common error so we start from the defined root definition and single out the following relevant activities in improving innovativeness: redefining the policy and strategies for innovation, identifying the activities for improving business-academia collaboration, developing new models of organizational structures at universities, specifying the activities to encourage students and teachers innovativeness, as well as activities needed to change the organizational culture and to adopt innovative organizational culture. Also, the model includes the monitoring and control activities along with defining the main criteria for assessing innovativeness in higher education. On that note, we emphasize the contribution to sustainable development as the criterion for effectiveness, and cost/benefit analysis as the criterion for efficiency. This model can help in deepening our understanding of the situation and enable us to begin to learn the way to taking actions to improve the problem situation. It is a device which is a source of good questions to ask about real situation and ensures a structured discussion about the situation, how it could be changed, which will eventually lead to action being taken.

According to the above, we can conclude that the given conceptual model represents a system by which innovativeness in higher education can be improved. Comparing conceptual models with reality should result in the discussion about changes that will improve the problem situation.

With respect to the listed characteristics of the current state of innovativeness in higher education (Lašáková et al., 2017), the debate on possible changes should lead to identifying the proper systemically desirable and culturally feasible changes, as the outcome of the comparison of the conceptual model with the current situation. From the 
conceptual model we can define a set of questions to ask. These are as follows: Does some activity exist in the real situation? Who does it? How do they do it? When do they do it? How else could it be done?, etc. Since this type of discussion was not conducted in real conditions, systemically desirable and culturally feasible changes have been identified, based on the comparison of the interpreted results of previous research on the current situation in HEIs with the activities identified in the conceptual model.

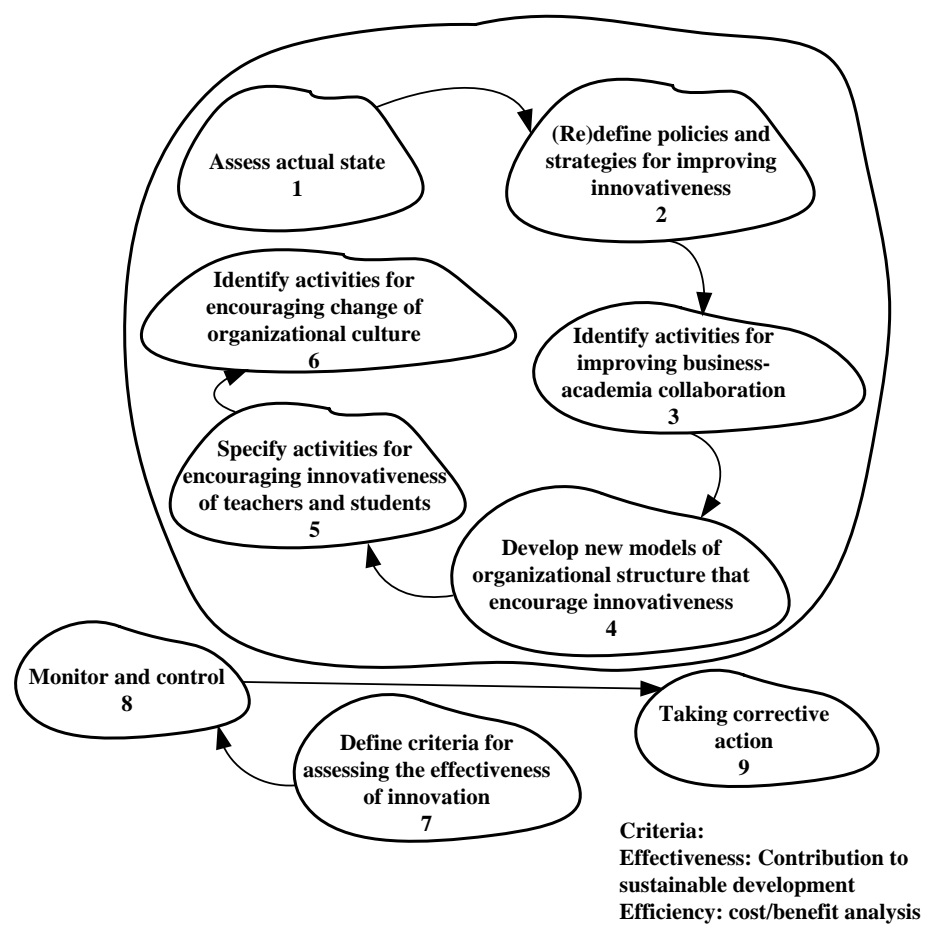

Figure 2 Conceptual model

Source: Adapted from Zlatanović, 2015

The changes in their nature may vary: changes in structure, changes in procedures and changes in attitudes. So, we propose several systemically desirable and culturally feasible changes. First of all, structural changes can refer to the changes in the organizational structure at universities that include the introduction of new organizational units in charge of innovation, such as, for example, the development of university spin-offs (Babić \& Savović, 2015), the changes in the reporting structure and the structure of responsibility. Procedural changes concern dynamic elements, such as the changes of the regulatory framework (e.g. accreditations procedures), the changes in reporting and information process, the decision- 
making process (for example, a greater participation of students in the decision-making process), and the like. Changes in attitudes involve flexible and innovative organizational culture, fostering teamwork and interdisciplinary cooperation. This type of changes also relates to changes in the expectations that relevant stakeholders have from improving innovativeness in HEIs. However, it often happens that the identified changes are not implemented in reality or that they are not sufficiently implemented. Therefore, monitoring and control activities have key importance, but also the assessment of effectiveness of implemented innovations envisaged by the conceptual model.

\section{DISCUSSION AND IMPLICATIONS}

Of relevant importance is to take into account that this is only the potential application of the SSM in improving innovativeness in higher education. It would be more beneficial if we could implement this approach in real circumstances. However, the limitation of the paper concerns the fact that the current state of innovativeness in higher education is assessed on the basis of the literature review and the results of previous studies, and not on the basis of an original empirical research. In this regard, the subject of future research is the assessment of the current situation at the universities in the Republic of Serbia and Slovenia and its comparison with the elements of the conceptual model, with the aim of defining the systemically desirable and culturally feasible changes that will lead to improving innovativeness in HEIs. One of the possible ways of assessing the current situation is the empirical research based on primary data collection through the distribution of the questionnaires to relevant stakeholders, as well as one based on secondary data analysis.

Hence, comparing the so identified current state with the elements of the conceptual model should trigger a certain discussion on the systemically desirable and culturally feasible changes between the relevant stakeholders. Even if such discussion would be allowed, a question on the real participation of stakeholders may be posed, given the different power they possess. This implies the need for a combined application of the SSM and the specific emancipatory systems approaches, such as Critical Systems Heuristics (Ulrich, 1994) in improving innovativeness of HEIs.

Regarding the effects of the proposed approach to innovativeness of higher education institutions we can stress that the SSM provides a learning system that challenges the existing ways of seeing and doing things, and can lead to some worldviews changes or new proposals for change. In comparison to some alternative approaches, such as hard systems approaches (classic Operational Research, Systems Analysis or Viable System Model), the SSM incorporates the concept of conflicting worldviews which characterizes all social interactions. According to 
Zlatanović (2016), the key differences between hard systems approaches (HSA) and the SSM as a representative of soft systems approaches are reflected in the interpretation of the system concept itself, the theoretical assumptions and methods used, as well as in the principles of acquiring knowledge. The HSA observes the system as an objective part of reality. On the other hand, the SSM does not see the system as an objective entity in the real world, but more as epistemological concept subjectively constructed by people. In addition to this, the HSA and the SSM are both based on different theoretical assumptions and use of different analysis methods. According to the HSA, a system should be well structured and with clearly defined objective. However, such approach implies optimization and cannot provide a solution for complex social problems since it ignores different perceptions, values and interests existing in organizations. On the contrary, SSM focuses on problem situations as the systems of problems, rather than on a single problem. Therefore, the focus is on the learning process. Finally, the HSA and the SSM base on the different principles of knowledge acquisition. The HSA correspond with traditional epistemology employing the principle of division between the subject and the object of research. On the other hand, SSM respects the interaction between the observer, as the subject of the research, and the problem situation, as the object of the research. Accordingly, the observer is part of the observed situation. Actually, in SSM social world is considered to be very complex and continually created and recreated by people thinking, talking and taking action. We can conclude that in the SSM, the concept of systemicity appears in the process of inquiry into the world, rather than in the world itself. This shift makes a difference between the hard and soft systems approaches (Reynolds and Holwell, 2010).

The utilization of the SSM methodology to address innovativeness in HEI may have the following theoretical and practical implications. Regarding the theoretical implications, we may outline several possible components of HEI, which should be taken into consideration when dealing with drivers and barriers or more broadly with innovativeness in HEI. This can for instance, be the institutional framework (modern ICT, government "support", accreditation standards; structural/procedural factors, organizational culture); intellectual capital (knowledge, upgrading knowledge, in-service training) and diverse aspects of innovativeness in HE (e-learning, flexibility, students can choose subjects, on-line teaching materials, students stimulating activities, student mobility, co-developing the curricula). Turning to practical implications, the utilization of outlined areas in the frame of empirical examination will enable various entities involved in HEI, for instance the assessment of key drivers and barriers of innovativeness in HEI, the identification of the current state of innovativeness in HEI from various standing points, etc. These cognitions provide fertile ground for future decisions of HEI about how to improve 
their innovativeness and the possibility for fine tuning of the individual elements of innovativeness in HEI.

\section{CONCLUSION}

On the basis of the overall consideration in the paper, we can draw the following conclusions: the SSM represents an appropriate means of introducing a structured systems thinking into a certain course of events and actions, which adjusts the various assessments of the investigated problem situation and introduces the proper models of the system. Due to different practical experiences regarding the use of the SSM, the following conclusion can be drawn: the SSM provides a structured way of identifying and involving different views of relevant stakeholders, highly applicable ideas, stakeholders who are open to new ideas and conflict mitigation, but also more willing to listen to alternative approaches and to adopt them.

In that sense, the key contribution of the paper consists in the introduction of the SSM as an appropriate systemic approach to improving innovativeness in higher education, the application of which has not been identified so far. In fact, conducting the research on improving innovativeness in higher education within the conceptual framework of the SSM and using its key tools provides a comprehensive review of the given problem situation and the possibilities for its improvement. Using our cognitions will be beneficial for addressing some of the current challenges of innovativeness in HEIs, like improving cooperation between the academia and economy (Potočan et al., 2016), where activities of HEIs should be oriented on establishing tighter connections, for instance in initiatives for solving actual problems of organizations, by including students in project work.

\section{REFERENCES}

Al-Husseini, S. and Elbeltagi, I. (2016). Transformational leadership and innovation: a comparison study between Iraq's public and private higher education. Studies in Higher Education, 41(1), 159-181.doi.org/10.1080/03075079. 2014.927848

Babić, V. \& Savović, S. (2015). Podsticajni faktori razvoja univerzitetskih spinof poduhvata (Incentive factors for the development of university spin-offs), $\mathrm{U}$ Mimović, P. (red). Univerzitetski spinof poduhvati - organizacioni okvir za realizaciju interdisciplinarnih projekata (University spinoffs - an organizational framework for the realization of interdisciplinary projects) (str. 33-67), Kragujevac: Univerzitet u Kragujevcu, Ekonomski fakultet.

Baregheh, A., Rowley, J. \& Sambrook, S. (2009). Towards a Multidisciplinary Definition of Innovation. Management Decision, 47 (8), 1323-1339. DOI 10.1108/ 00251740910984578 
Bennet, L. M. \&Kerr, M. A. (1996). A Systems Approach to the Implementation of Total Quality Management. Total Quality Management, 7 (6), 631-665. DOI 10.1080/09544120100000022

Bennetts, P. D. C., Mills, S. \& Wood-Harper, A.T. (2000). Role-play in inquiring systems and information systems development. Systems Research and Behavioral Science,17, 231-242.Doi 10.1002/(SICI)1099-1743(200005/06) 17:3<231::AID-SRES317>3.0.CO;2-B

Bouchikhi, H. \& Kimberly, R. (2001). It's difficult to innovate': The death of the tenured professor and the birth of the knowledge entrepreneur. Human Relations, 54(1), 77-84. doi:10.1177/0018726701541010

Brennan, J., Ryan, S., Ranga, M., Broek, S., Durazzi, N., Kamphuis, B. (2014). Study on innovation in higher education: Final Report Study on Innovation in Higher Education Executive Summary.

Carayannis, E. G., \& Rakhmatullin, R. (2014). The Quadruple/Quintuple Innovation Helixes and Smart Specialisation Strategies for Sustainable and Inclusive Growth in Europe and Beyond. Journal of the Knowledge Economy, 5(2), 212-239. doi: 10.1007/s13132-014-0185-8

Checkland, P. (1996). Systems Thinking, Systems Practice. Chichester: John Wiley and Sons

Checkland P. (2000). Soft Systems Methodology: A Thirty Year Retrospective. Systems Research and Behavioral Science, 17 (S1), 11-58.

Checkland, P. \& Tsouvalis, C. (1997). Reflecting on SSM: The Link Between Root Definitions and Conceptual Models. Systems Research and Behavioral Science, 14 (3), 153-168. doi.10.1002/(SICI)1099-1743(199705/06)14:3 $<153:: A I D-S R E S 134>3.0 . C O ; 2-\mathrm{H}$

Checkland, P., \& Poulter, J. (2010). Soft Systems Methodology. In M. Reynolds, \& S. Holwell (Eds.), Systems Approaches to Managing Change: A Practical Guide (pp. 191-242). London: Springer

Díaz-Parra, O.; Ruiz-Vanoye, J. A.; Barrera-Cámara, R. A.; Fuentes-Penna, A. \& Sandoval, N. (2014). Soft Systems Methodology for the Strategic Planning of the Enterprise Computer Security. International Journal of Combinatorial Optimization Problems and Informatics, 5(1), 2-14.

Ellis, D. (2015). What Discourages Students from Engaging with Innovative Instructional Methods: Creating a Barrier Framework. Innovative Higher Education, 40, 111-125.DOI 10.1007/s10755-014-9304-5

European Commission (2010). Europe 2020 Strategy. available at: http://aei.pitt. edu/47687/1/Europe_2020.pdf

EuropeanUnion. (2006). Innovation Management and the Knowledge-Driven Economy. Brussels: European Union.

Fahey, D. K., Carson, E. R., Cramp, D. G. \& Muir Gray, J. A. (2004). Applying Systems Modelling to Public Health. Systems Research and Behavioral Science, 21, 635-649.doi.org/10.1002/sres.602

Foss, N. J., \& Saebi, T. (2017). Fifteen Years of Research on Business Model Innovation: How Far Have We Come, and Where Should We Go? Journal of Management, 43(1), 200-227. doi: 10.1177/0149206316675927

García, M. L. \& Roblin, P. N. (2008). Innovation, research and professional development in higher education: Learning from our own experience. Teaching and Teacher Education, 24 (1), 104-116.doi:10.1016/j.tate.2007.03.007

Garrison, D.R. \& Kanuka, H. (2004). Blended learning: uncovering its transformative potential in higher education. Internet and Higher Education, 7 (2), 95-105. 
Gregory, W. J. \& Midgley, G. (2000). Planning for disaster: developing a multiagency counselling service. Journal of the Operational Research Society, 51, 278-290.doi.org/10.1057/palgrave.jors.2600912

Hasanefendic, S., Birkholz, J.M., Horta, H. \& van der Sijde, P. (2017). Individuals in action: bringing about innovation in higher education. European Journal of Higher Education, 7 (2), 101-119.doi.org/10.1080/21568235.2017.1296367

Jacobs, B. (2004). Using Soft Systems Methodology for Performance Improvement and Organisational Change in the English National Health Service,Journalof Contingenciesand CrisisManagement, 12 (4), 138-149.doi.org/10.1111/j.09660879.2004.00444.x

Klomp, L. \& Leeuwen, G. (2001). Linking Innovation and Firm Performance: A New Approach. International Journal of the Economics of Business, 8 (3), 343364. DOI: $10.1080 / 13571510110079612$

Kunnari, I. \& Ilomäki, L. (2016). Reframing teachers' work for educational innovation. Innovations in Education and Teaching International, 53 (2), 167-178.doi.org/ 10.1080/14703297.2014.978351

Lašáková, A., Bajzíková, L. \& Dedze, I. (2017). Barriers and drivers of innovation in higher education: Case study-based evidence across ten European universities. International Journal of Educational Development, 55, 69-79.doi.org/10.1016/ j.ijedudev.2017.06.002

Lockett, N., Brown, D. \& Sissons, A.(2006). Soft Systems Methodology in IT Project Management: Implementing CRM inSMEs. AMCIS 2006 Proceedings (37223732).

Loffler, K., Tschirky, H. \&Kijima. K.J. (2009). Embedding Enterprise Science into SSM for Improving Innovation Systems in Technology-Based Companies. Systems Research and Behavioral Science, 26, 675-687.doi.org/10.1002/sres.962

Maje, M \& Sunjka, B. P. (2014).The Application of Soft Systems Methodology to Supply Chain Risk Management in Small and Medium Enterprises. In (Schutte, C. ed.) Southern African Institute for Industrial Engineering SAIIE26 Proceedings (pp. 317-331).

Nedelko, Z. \& Potočan, V. (2013). The role of management innovativeness in modern organizations. Journal of Enterprising Communities: People and Places in the Global Economy, 7 (1), 36-49. doi.org/10.1108/17506201311315590

Neves, L.M.P., Martins, A. G., Antunes, C. H. \& Dias, L.C. (2004). Using SSM to rethink the analysis of energy efficiency initiatives. Journal of the Operational Research Society, 55, 968-975. doi.org/10.1057/palgrave.jors.2601763

OECD (2016). Innovating Education and Educating for Innovation: The Power of Digital Technologies and Skills, OECD Publishing. Paris. Available at: http://dx.doi.org/10.1787/9789264265097-en

Petrović, S. P. (2013). A Holistic Instrumentarium for Creative Managing the Problem Situations. Teme, 37 (1), 97-116.

Potocan, V., Nedelko, Z., Mulej, M., \& Dabic, M. (2016). How University's Activities Support the Development of Students' Entrepreneurial Abilities: Case of Slovenia and Croatia. Journal of the Knowledge Economy, 1-19. doi: 10.1007/s13132-016-0407-3

Presley, A., Sarkis, J. \&Liles, D. (1998). Participative Design Using Soft Systems Methodology, AMCIS Proceedings, 270.

Roffei, M. H. S., Kamarulzaman, Y. \& Yusop, D. F. (2016). Innovation culture in higher learnign instituions: A proposed framework. Procedia - Social and Behavioral Sciences, 219, 401-408.doi.org/10.1016/j.sbspro.2016.05.064

Rogers, E. (2003). Diffusion of Innovations. New York: Free Press. 
Serdykov, P. (2017). Innovation in education: what works, what doesn't, and what to do about it? Journal of Research in Innovative Teaching \& Learning, 10(1), 4-33.

Skarzynski, P., \& Gibson, R. (2008). Innovation to the core. Boston, MA: Harvard Business Press.

Smith, K. (2000). Innovation as a Systemic Phenomenon: Rethinkingthe Role of Policy. Enterprise \& Innovation Management Studies, 1(1), 73102.doi.org/10.1080/146324400363536

Tierney, W.G. and Lanford, M. (2016b). Conceptualizing Innovation in Higher Education. In: Paulsen, M. (ed.) Higher Education: Handbook of Theory and Research (pp.1-32), Vol. 31, Springer

Ulrich, W. (1994). Critical Heuristics of Social Planning - A New Approach to Practcal Philosophy. Chichester: John Wiley and Sons

Yadin, A. (2013). Soft Systems Methodology in an EducationalContext-Enhancing Students Perception and Understanding. International Journal of e-Education, $e$ Business, e-Management and e-Learning, 3 (5), 351-356.DOI: 10.7763/IJEEEE. 2013.V3.25

Valenčić-Zuljan, M. and Vogrinc, J. (eds). (2010). Facilitating Effective Student Learning through Teacher Research and Innovation. Ljubljana: Faculty of Education

Zlatanović, D. (2015). A Holistic Approach to Corporate Social Responsibility as a Prerequisite for Sustainable Development: Empirical Evidence, Economic Annals, 60, 69-94.DOI:10.2298/EKA1507069Z

Zlatanović, D. \& Mulej, M. (2015). Soft-systems approaches to knowledge-cumvalues management as innovation drivers, Baltic Journal of Management, 10 (4), 497-518. doi.org/10.1108/BJM-01-2015-00

Zlatanović, D. (2016). Kombinovanje metodologija Identifikovanja i testiranja strategijskih pretpostavki i Organizacione kibernetike u upravljanju problemskim situacijama u preduzećima (Combining the methodologies of Strategic Assumptions Surfacing and Testing and Organizational Cybernetics in managing the problem situations in enterprises). Ekonomski horizonti, 18(1), 15-32. doi: 10.5937/ekonhor1601015Z,

Zlatanović, D. \& Nikolić, J. (2017). Strategic decision making from the viewpoint of systems thinking: the role of values and context. In: Nedelko, Z. \& Brzozowski, M. (eds). Exploring the influence of personal values and cultures in the workplace (98-118). IGI Global, Hershey: Business Science Reference

Zlatanović, D., Babić, V. \& Nikolić, J. (2020). Higher Education Institutions as Viable Systems: A Cybernetic Framework for Innovativeness. In: Babić, V. \& Nedelko, Z. (eds). Handbook of Research on Enhancing Innovation in Higher Education Institutions (1-25). IGI Global, Hershey: Business Science Reference 


\title{
СИСТЕМСКИ ПРИЛАЗ УНАПРЕЪЕЊУ ИНОВАТИВНОСТИ У ВИСОКОМ ОБРАЗОВАЮУ
}

\author{
Дејана Златановић ${ }^{1}$, Јелена Николић ${ }^{1}$, Златко Неделко ${ }^{2}$ \\ ${ }^{1}$ Универзитет у Крагујевцу, Економски факултет, Крагујевац, Србија \\ ${ }^{2}$ Универзитет у Марибору, Факултет за економију и бизнис, Марибор, Словенија
}

\section{Резиме}

Поштујући значај иновативности за остваривање конкурентске предности и одрживи развој савремених организација, у раду је средиште истраживања на иновативности високообразовних институција и могућностима њеног унапређења. Сходно сложеној и плуралистичкој природи истраживаног проблемског подручја, примењен је одговарајући холистички прилаз унапређењу иновативности у високом образовању. Заправо, иновативност у високом образовању је посматрана у концепцијском оквиру Методологије тзв. софт система (МСС). Као одговарајућа интерпретативна системска методологија, МСС настоји да обухвати различите перцепције реалности, олакшавајући на тај начин процес учења у коме су различита схватања испитана и дискутована на начин који доводи до осмишљеног деловања и унапређења. Иако представља једну од најшире употребљаваних системских методологија, још увек није примењена у проблемској области унапређења иновативности у високом образовању, што представља одговарајућу истраживачку празнину. У превазилажењу наведеног истраживачког гепа, у раду су коришћене богате слике, изворне дефиниције и концептуални модели, као релевантни инструменти MCC-а. На тај начин, препознате су различите перцепције релевантих стејкхолдера о унапређењу иновативности у високом образовању, као и могуће системски пожељне и културално изводиве промене којима се може унапредити иновативност високообразовних институција. Дакле, истражујући иновативност у високом образовању у концепцијском оквиру МСС-а и користећи њене кључне инструменте, обезбеђено је свеобухватно сагледавање дате проблемске ситуације и могући начини њеног унапређивања. Међутим, важно ограничење тиче се чињенице да је текуће стање иновативности у високом образовању процењено на основу прегледа литературе и резултата претходних истраживања, а не на основу оригиналног емпиријског истраживања. У том смислу, предмет будућих истраживања је процена текућег стања на универзитетима у Републици Србији и Словенији и њихово поређење са елементима концептуалног модела, у циљу дефинисања системски пожељних и културално изводивих промена које ће довести до унапређења иновативности на високообразовним институцијама. Један од могућих начина процене текућег стања је емпиријско истраживање засновано на прикупљању примарних података кроз дистрибуцију упитника релевантним стејкхолдерима, као и на анализи секундарних података. 